Wanda Kamińska ${ }^{1}$, Monika Grochowska ${ }^{2}$, Agnieszka Chmielarczyk ${ }^{3}$, Anna Olszewska Grażyna Skolimowska ${ }^{5}$, Katarzyna Dzierżanowska-Fangrat ${ }^{1}$

\title{
GENETIC TYPING OF ENTEROCOCCUS FAECIUM VRE STRAINS ISOLATED IN THREE HOSPITALS IN WARSAW AND SIEDLCE IN 2015-2016
}

\author{
GENETYCZNE TYPOWANIE SZCZEPÓW VRE ENTEROCOCCUS FAECIUM \\ WYIZOLOWANYCH W TRZECH SZPITALACH W WARSZAWIE ORAZ \\ W SIEDLCACH W LATACH 2015-2016
}
${ }^{1}$ The Children's Memorial Health Institute, Warsaw, the Department of Microbiology and Clinical Immunology ${ }^{2}$ The Children's Memorial Health Institute, Warsaw, the Infection Control Committee ${ }^{3}$ The Jagiellonian University, Collegium Medicum, The Department of Bacteriology, Parasitology and Ecology of Microorganisms
${ }^{4}$ Grochowski Hospital, Warsaw, the Diagnostic Analytical Laboratory, Microbiology Centre ${ }^{5}$ Mazowiecki Provincial Hospital in Siedlce
${ }^{1}$ Instytut „Pomnik - Centrum Zdrowia Dziecka” Warszawa, Zakład Mikrobiologii i Immunologii Klinicznej
${ }^{2}$ Instytut „Pomnik - Centrum Zdrowia Dziecka” Warszawa, Zespół Zakażeń Szpitalnych
${ }^{3}$ Uniwersytet Jagielloński, Collegium Medicum, Zakład Bakteriologii, Parazytologii i Ekologii Drobnoustrojów
${ }^{4}$ Szpital Grochowski, Warszawa, Diagnostyczne Laboratorium Analityczne, Pracownia Mikrobiologii ${ }^{5}$ Mazowiecki Szpital Wojewódzki w Siedlcach

\section{ABSTRACT}

INTRODUCTION. Since the first report of vancomycin-resistant enterococci (VRE) in Poland, in 1996, these strains have spread in Polish hospitals, mainly due to selective pressure associated with increased use of vancomycin in the treatment of infections caused by methicillin-resistant staphylococci and Clostridium difficile. At the beginning of 2016 a growing number of patients colonized with VRE in the gastrointestinal tract was observed in the Children's Memorial Health Institute (IPCZD). Some of these patients were transferred from other hospitals, and VRE colonization was found on admission.

AIM. To analyze genetic similarity of VRE strains isolated from patients hospitalized in IPCZD and two other hospitals in Mazovian district, genetic typing by pulsed field gel electrophoresis (PFGE) was performed.

MATERIALS AND METHODS. VRE strains were isolated from rectal swabs, and other clinical samples such as blood, cerebrospinal fluid, other body fluids, and environmental samples. A total of 56 VRE strains from IPCZD, 20 strains from Siedlce and 4 strains from patients from Grochowski Hospital in Warsaw were typed by PFGE.

RESULTS. PFGE typing revealed 4 VRE clones containing several strains with identical restriction patterns. Among VRE strains isolated from neonates hospitalized in IPCZD, two clones with 24 and 20 identical strains were found. Respectively, $16(67 \%)$ and $12(60 \%)$ isolates were originated from rectal swabs from patients at admission to the hospital. Clonal strains were identified in all three hospitals included in the study.

CONCLUSIONS. Our results showed that VRE strains had spread in the region. Isolation of clonal strains on admission to the hospital suggested independent VRE introductions from environment or other hospitals. Identification of clonal strains obtained from rectal swabs and other clinical samples during hospitalization indicated horizontal transmission.

Key words: E. faecium, VRE, PFGE, clonal strains

\section{STRESZCZENIE}

WSTĘP. Od czasu pierwszego doniesienia o izolacji enterokoków oporntych na wankomycynę (VRE) w Polsce w 1996 roku, szczepy te bardzo rozpowszechniły się w polskich szpitalach, na skutek selekcji spowodowanej m.in.

(C) National Institute of Public Health - National Institute of Hygiene / Narodowy Instytut Zdrowia Publicznego - Państwowy Zakład Higieny 
zwiększonym zużyciem wankomycyny w leczeniu zakażeń wywołanych przez gronkowce metycylinooporne (methicillin-resistant Staphylococcus aureus, MRSA, methicillin resistant coagulase-negative staphylococci, MRCNS) oraz Clostridium difficile. Na początku 2016 roku w Instytucie Pomnik Centrum Zdrowia Dziecka (IPCZD) coraz częściej zaczęli pojawiać się pacjenci skolonizowani VRE w przewodzie pokarmowym. Część z nich trafiała z innych szpitali, a kolonizację często stwierdzano w badaniu przesiewowym przy przyjęciu.

CEL. Analiza pokrewieństwa genetycznego szczepów VRE izolowanych od pacjentów PCZD oraz 2 innych szpitali na Mazowszu przeprowadzona za pomocą typowania genetycznego metodą elektroforezy pulsacyjnej (pulsed field electrophoresis, PFGE).

MATERIALY I METODY. Szczepy VRE izolowano z rutynowo pobieranych wymazów z odbytu oraz z innych materiałów klinicznych, takich jak: krew, płyn mózgowo-rdzeniowy, płyn z otrzewnej, a także ze środowiska pacjentów skolonizowanych / zakażonych. Typowanie objęło 56 szczepów VRE z IPCZD, 20 szczepów izolowanych od pacjentów szpitala w Siedlcach oraz 4 szczepy ze szpitala Grochowskiego w Warszawie.

WYNIKI. Typowanie PFGE wykazało obecność 4 klonów obejmujących szczepy o identycznych wzorach restrykcyjnych. Wśród szczepów VRE izolowanych od pacjentów oddziału noworodkowego IPCZD wykryto obecność 2 klonów liczących 24 i 20 szczepów o identycznych wzorach restrykcyjnych. Odpowiednio, 16 (67\%) i $12(60 \%)$ izolatów pochodziło z wymazów z odbytu pobranych w dniu przyjęcia. Podobne do siebie szczepy klonalne izolowano w IPCZD, szpitalu Grochowskim i w szpitalu w Siedlcach.

WNIOSKI. Zjawisko to świadczy o rozpowszechnieniu klonalnych szczepów VRE w środowisku regionu. Izolacja szczepów klonalnych z wymazów z odbytu od kilku pacjentów, pobranych w dniu przyjęcia do szpitala, wskazuje na niezależne introdukcje VRE do szpitala ze środowiska pozaszpitalnego. Izolacja szczepów klonalnych z wymazów z odbytu oraz innych materiałów klinicznych uzyskanych od pacjentów w trakcie hospitalizacji (w tym od pacjentów z tego samego oddziału) świadczy o licznych przypadkach transmisji horyzontalnej.

Słowa kluczowe: E. faecium, VRE, PFGE, szczepy klonalne

\section{INTRODUCTION}

Enterococci are commensal microorganisms of the human and animal digestive tract. They are Grampositive cocci with few virulence factors that enable them to actively cause infections only in people from risk group. They are characterized, however, by their resistance - both natural and acquired - to several antibiotic groups. As opportunistic microorganisms they cause infections in patients with immunosuppression, subjected to long-term antibiotic therapy, patients with serious basic diseases, patients after organ transplants and patients with cancer. They may be dangerous for the people of extreme age groups - newborns, preterm neonates and the elderly. They are one of the most common etiological factors of hospital-acquired infections of the urinary system, infections of wounds and bacteraemias in patients from risk groups. The main reason for the subsistence of Enterococci in hospital environment is their natural resistance to a number of commonly used antibiotics and their ability to gain resistance through mutation or horizontal gene transfer. The natural resistance of Enterococci involves cephalosporins, low concentrations of aminoglycosides, trimethoprim/ sulphamethoxazole, lincosamides, low concentrations of glycopeptides in E. gallinarum and E. casseliflavus species (VanC phenotype) and decreased susceptibility to penicillin that characterizes E. faecium . Enterococci also have mechanisms of acquired resistance out of

\section{WSTĘP}

Enterokoki są drobnoustrojami komensalnymi przewodu pokarmowego człowieka i zwierząt. Są to Gram-dodatnie ziarniaki posiadające nieliczne czynniki zjadliwości umożliwiające aktywne wywoływanie zakażeń jedynie u osób z grupy ryzyka, natomiast charakteryzują się zarówno naturalną, jaki i nabytą opornością na kilka grup antybiotyków. Jako drobnoustroje oportunistyczne powodują zakażenia u pacjentów w immunosupresji, poddawanych długotrwałej antybiotykoterapii, z poważnymi chorobami podstawowymi, po przeszczepieniach narządów i chorych na nowotwory. Groźne mogą być dla osób w skrajnych grupach wiekowych - noworodków i wcześniaków oraz osób w podeszłym wieku. U chorych z grup ryzyka są jednym z najczęstszych czynników etiologicznych szpitalnego zakażenia układu moczowego, zakażenia ran i bakteriemii. Główną przyczyną utrzymywania się enterokoków w środowisku szpitalnym jest wrodzona oporność tych bakterii na szereg powszechnie stosowanych antybiotyków, a także zdolność nabywania cech oporności na drodze mutacji lub przez horyzontalny transfer genów. Oporność naturalna enterokoków obejmuje cefalosporyny, niskie stężenia aminoglikozydów, trimetoprim/sulfametoksazol, linkosamidy, niskie stężenia glikopeptydów u gatunku E. gallinarum i E. casseliflavus (fenotyp VanC) oraz właściwą dla E. faecium obniżoną wrażliwość na penicyliny. Enterokoki posiadają również mechanizmy oporności na- 
which the following three have the highest clinical and epidemiological significance: resistance to high concentration levels of the aminoglycoside antibiotics (high level aminoglycoside resistance, HLAR), vancomycin/glycopeptide resistance (Vancomycin/ glycopeptide resistant enterococci, VRE/GRE) and linezolid resistance (linezolid resistant enterococci, LRE). Amongst the strains of Enterococcus sp. 8 phenotypes of acquired vancomycin resistance have been described: VanA, VanB, VanD, VanE, VanG, VanL, VanM and VanN $(1,2)$. There is also one known phenotype of natural resistance - VanC which is unique for E. gallinarum and E. casseliflavus species (3). VanA and VanB phenotypes have the highest clinical significance. The phenotypes are dependent on genotypes acquired relatively recently by Enterococcus species. These phenotypes were primarily described in E. faecalis and E. faecium. The location VanA and VanB phenotype related genes on mobile genetic elements (on plasmids and transposons) conditions high outbreak potential of these strains (4).

VanA resistance phenotype. The strains with VanA resistance phenotype are characterized by high level inductive resistance to vancomycin (minimal inhibitory concentration, MIC > $64 \mu \mathrm{g} / \mathrm{ml}$ ) and teicoplanin ( $\mathrm{MIC}>16 \mu \mathrm{g} / \mathrm{ml}$ ) (4). The resistance is induced by glycopeptides applied in medicine and farming and by preparations other than glycopeptides, such as bacitracin, polymixin B and robenidine products used to control infectious diseases in poultry. Genotype that conditions VanA phenotype is located on mobile genetic element - transposon Tn1546 (1).

VanB resistance phenotype. It is now clear that the level of vancomycin resistance among VanB phenotype isolates may vary between MIC value that equals $4 \mathrm{mg} / \mathrm{ml}$ and $1024 \mathrm{mg} / \mathrm{ml}$, with susceptibility to teicoplanin being maintained. Factors that determine VanB phenotype may also be located on mobile genetic elements which may be transferred among Enterococci strains.

From the point of view of hospital epidemiology the acquired resistance of Enterococci to glycopeptide antibiotics is of the highest significance. The strains isolated in Poland are mostly vancomycin-resistant strains (VRE) from Enterococcus faecium $(4,5)$ species. Due to the activity of glycopeptides against strains of meticillin-resistant staphylococci and other Grampositive bacteria, these antibiotics were widely used in the treatment of infections with these microorganisms. Administrated orally vancomycin that is absorbed poorly in the digestive tract is chosen medication in the treatment of enterocolitis of Clostridium difficile etiology, thereby the selection of glycopeptide-resistant bacteria. The first isolation of vancomycin-resistant strains of E. faecalis and E. faecium was reported in 1988 in England. Soon, VRE was isolated in France bytej, spośród których największe znaczenie kliniczne i epidemiologiczne mają trzy z nich: oporność na wysokie stężenia antybiotyków aminoglikozydowych (high level aminoglycoside resistance, HLAR), oporność na wankomycynę / glikopeptydy (vancomycin / glycopeptide resistant enterococci, GRE/VRE) oraz oporność na linezolid (linezolid resistant enterococci, LRE). Wśród szczepów Enterococcus sp. opisano 8 fenotypów nabytej oporności na wankomycynę: VanA, VanB, VanD, VanE, VanG, VanL, VanM i VanN $(1,2)$. Znany jest także jeden fenotyp oporności naturalnej - VanC, który jest unikatowy dla gatunków E. gallinarum oraz E. casseliflavus (3). Największe znaczenie kliniczne mają fenotypy VanA oraz VanB zależne od zespołów genów stosunkowo niedawno ewolucyjnie nabytych przez rodzaj Enterococcus. Fenotypy te opisano przede wszystkim u E. faecalis $i$ E. faecium. Lokalizacja genów związanych $\mathrm{z}$ fenotypem VanA i VanB na ruchomych elementach genetycznych (plazmidach i transpozonach) warunkuje wysoki potencjal epidemiczny tych szczepów (4).

Fenotyp oporności VanA. Szczepy o fenotypie oporności VanA charakteryzują się indukcyjną opornością wysokiego stopnia na wankomycynę (minimal inhibitory concentration, MIC $>64 \mu \mathrm{g} / \mathrm{ml}$ ) i teikoplaninę (MIC $>16 \mu \mathrm{g} / \mathrm{ml}$ ) (4). Oporność jest indukowana przez glikopeptydy stosowane w lecznictwie i rolnictwie, oraz przez preparaty inne niż glikopeptydy, takie jak bacytracyna, polimyksyna B i robenidyna - środki używane do zwalczania zakażeń u drobiu. Zespół genów warunkujący fenotyp VanA znajduje się na ruchomym elemencie genetycznym - transpozonie Tn1546 (1).

Fenotyp oporności VanB. Obecnie wiadomo, że poziom oporności na wankomycynę wśród izolatów o fenotypie VanB może wahać się pomiędzy wartością MIC równą $4 \mathrm{mg} / \mathrm{ml}$ i $1024 \mathrm{mg} / \mathrm{ml}$, przy zachowaniu wrażliwości na teikoplaninę. Determinanty decydujące o fenotypie VanB również znajdują się na ruchomych elementach genetycznych, które mogą być przenoszone pomiędzy szczepami enterokoków.

Z punktu widzenia epidemiologii szpitalnej największe znaczenie ma nabyta oporność enterokoków na antybiotyki glikopeptydowe. W Polsce izolowane są głównie wankomycyno-oporne szczepy (VRE) z gatunku Enterococcus faecium $(4,5)$. Ze względu na aktywność glikopeptydów wobec szczepów gronkowców opornych na metycylinę, a także innych bakterii Gram-dodatnich, antybiotyki te były szeroko stosowane w leczeniu zakażeń tymi drobnoustrojami. Doustnie podawana wankomycyna, która słabo wchłania się z przewodu pokarmowego, jest lekiem z wyboru w leczeniu enterocolitis o etiologii Clostridium diffcile, stąd selekcja bakterii opornych na glikopeptydy. W 1988 roku doniesiono o pierwszym wyizolowaniu szczepów E. faecalis $i$ E. faecium opornych na wanko- 
and the other countries of the United Kingdom as well as in the eastern part of the USA. In the USA, VRE spreaded unexpectedly fast and now is widespread in hospitals, care institutions and homes for war veterans. In Poland, the first strains of VRE were isolated in the Hematology Clinic in Gdańsk in 1996 (5).

The report of European Antimicrobial Resistance Surveillance Network from 2016 (6) places Poland in the group of countries with a percentage of the vancomycin-resistant Enterococcus faecium strains at the level of approx. $25 \%$, which is similar to Hungary, Slovakia, Greece and Latvia. E. faecium VRE were found in our country in 1996 and, so far, epidemic outbreaks caused by VRE strains occurred sporadically in Poland, mostly in oncology and transplant units, and they occurred only at local levels. Between 2012 and 2014 epidemic outbreaks of E.faecium VRE etiology constituted $1-2 \%$ of the reported hospital-acquired infection outbreaks. They most commonly occurred as surgical site infections, often causing infections mixed with another pathogen present in the hospital (7). It seems that, like nowadays, in the nearest future Gram-negative hospital pathogens are and will be more significant than VRE: multiple-resistant Enterobactericeae bacilli, Pseudomonas aeruginosa and Acinetobacter sp. Enterococci colonize and cause infections mostly in specified patient groups: hematological, oncological, patients undergoing transplants; most outbreaks were described in these hospital units. $(7,8,9)$. A species among enterococci with definitely highest outbreak potential is E.faecium $(9,10,11)$.

In The Children's Memorial Health Institute (Instytut "Pomnik - Centrum Zdrowia Dziecka IPCZD) screening tests for alert pathogens in patients admitted to medical treatment facilities have been done since 2002. In 2012 the patients who were hospitalized within the last month in another hospital were also included in these tests, and in 2016 testing of nose and rectal swabs was recomended in all newly admitted patients (due to Klebsiella pneumoniae NDM strains). The number of screening tests was growing annually from about 500 between 2002-2005, through 2-3 thousand in the years 2005-2010, to 10 thousand in the years $2010-2014$ and 14 thousand in the years 2015-2017 (in the indicated years the number of the hospitalized patients remained at the same level of approx. 40 thousand. a year). At the beginning of 2016, in IPCZD, patients with VRE colonization in the digestive tract started appearing increasingly, initially in the Neonatal Unit, Neonatal Pathology and Intensive Care Unit (Klinika Patologii i Intensywnej Terapii Noworodka - OITN) and then, subsequently, in the Urology Unit (Klinika Urologii - OUR) and also in several other units. Conduct the screening tests mycynę w Anglii. Niedługo potem wyizolowano VRE we Francji i innych krajach Zjednoczonego Królestwa, a także we wschodniej części USA. W USA VRE rozprzestrzeniły się niespodziewanie szybko i obecnie powszechnie występują w szpitalach, domach opieki i domach dla weteranów. W Polsce pierwsze szczepy VRE wyizolowano w Klinice Hematologii w Gdańsku w 1996 roku (5).

Raport European Antimicrobial Resistance Surveillance Network z 2016 (6) roku sytuuje Polskę w gronie państw o odsetku opornych na wankomycynę szczepów Enterococcus faecium na poziomie ok. $25 \%$, podobnie do Węgier, Słowacji, Grecji i Łotwy. E. faecium VRE wykryto w naszym kraju w 1996 roku, i jak dotąd, ogniska epidemiczne wywoływane przez szczepy VRE występowały w Polsce sporadycznie, głównie w oddziałach onkologicznych i transplantacyjnych, i miały zasięg lokalny. W latach 2012-2014 ogniska epidemiczne o etiologii E. faecium VRE stanowily 1-2\% zgłoszonych ognisk zakażeń szpitalnych, w których najczęściej występowały pod postacią zakażenia miejsca operowanego, często powodując zakażenia mieszane $\mathrm{z}$ innym patogenem szpitalnym (7). Wydaje się, że tak jak obecnie, w najbliższej przyszłości istotniejszą rolę od VRE odgrywają i będą odgrywać Gram-ujemne patogeny szpitalne: wielooporne pałeczki Enterobacteriaceae, Pseudomonas aeruginosa i Acinetobacter sp. Enterokoki kolonizują i wywołują zakażenia głównie u określonych grup pacjentów: hematologicznych, onkologicznych, transplantologicznych, i w tych oddziałach opisano większość epidemii $(7,8,9)$. Wśród enterokoków gatunkiem o zdecydowanie największym potencjale epidemicznym jest $E$. faecium $(9,10,11)$.

W Instytucie „Pomnik-Centrum Zdrowia dziecka” (IPCZD) od 2002 roku prowadzone są badania przesiewowe (wymazy z nosa i z odbytu) w kierunku patogenów alarmowych u pacjentów przyjmowanych do oddziałów zabiegowych. W roku 2012 badania te rozszerzono na nowo przyjmowanych pacjentów, którzy w ciągu ostatniego miesiąca byli hospitalizowani $\mathrm{w}$ innym szpitalu, a w roku 2016 zalecono pobieranie wymazów z nosa i odbytu od wszystkich nowo przyjmowanych pacjentów (ze względu na szczepy Klebsiella pneumoniae NDM). Liczba badań przesiewowych wzrastała rocznie z około 500 w latach 2002-2005, poprzez 2-3 tysiące w latach 2005-2010, do 10 tysięcy w latach 2010-2014 i 14 tysięcy w latach 2015-2017 (liczba hospitalizowanych utrzymywała się we wszystkich latach na stałym poziomie ok. 40 tys. rocznie). Na początku 2016 roku w IPCZD coraz częściej zaczęli pojawiać się pacjenci skolonizowani VRE w przewodzie pokarmowym, początkowo w Klinice Neonatologii, Patologii i Intensywnej Terapii Noworodka (OITN), a następnie w Klinice Urologii (OUR) a także w kilku innych oddziałach. Wykonanie badania przesiewowego wymazu z odbytu w dniu przyjęcia pa- 
for alert pathogens on the day of patient admission to the hospital enabled the elimination of pathogen acquisition in the IPCZD but in many cases without screening rectal swabs, we cannot excluded acquisition of VRE in our hospital and horizontal transfer of VRE strains among patients was immediately suspected, for example in cases of tested rectal swab after 2 or more days of hospitalization. As a part of an epidemiological investigation in IPCZD PFGE genetic typing of 43 VRE isolates isolated in the first six months of 2016 and 14 isolates from 2015 was carried out. The typing of 24 VRE strains from the same period, carried out for two different hospitals (the Grochowski Hospital and the Provincial Hospital in Siedlce), made genetic comparison of strains occurring in the region possible.

\section{MATERIALS AND METHODS}

Genetic typing included all Enterococcus faecium VRE isolates obtained from the IPCZD patients in the first six months of 2016 and 14 isolates from the last quarter of 2015 as well as all isolates from analogical period sent by the Provincial Hospital in Siedlce (20 strains) and the Grochowski Hospital (4 strains) in Warsaw. The isolates were obtained from the following material: rectal swab (57, from which $25 / 44 \%$ was at admission), blood (2), urine (6), wound (10), mini BAL (1) , intra-abdominal swab (3), central venous catheter end (1); furthermore one environmental isolate from IPCZD - a swab from body temperature sensor on skin. Mentioned clinical materials was tested during hospitalization.

In the period of typing strains (1.10.2015 $31.07 .2016)$ to OITN was admitted the 1665 patients; from 1349 of them was done screening rectal swab at admission. From 47 VRE strains from rectal swabs in IPCZD, 35 was isolated at admission and 12 others strains came from screenings in time of hospitalization (7-54 days, of average after 14 days; at OITN screening rectal swabs was tested once a week in all patients). All the VRE isolates from IPCZD (57 strains) was PFGE typing: 47 strains from the rectal swabs (each from another child), 5 strains from the urine, 4 strains from the wounds, one strain from the the blood. All clinical samples (without rectal swabs) from hospital from Siedlce (urine - 4 strains, wounds -4, mini Bal -1, peritoneum swab -3 , central catheter -1$)$, and from Grochowski Hospital (one strain from the blood, one from the urine, and 2 strains from wounds) was tested for clinical indications during hospitalization (in time 5-28 days of hospitalization, of average after 12 days. Rectal swabs from Siedlce tested after the isolation of VRE from other clinical samples, in order to confirm or exclude the colonization. The environmental samples in IPCZD (swabs from medical apparatus, furniture, cjenta do szpitala pozwala na wykrycie patogenu alarmowego. W przypadku braku takiego badania możliwa jest zarówno wcześniejsza kolonizacja pacjenta, jak i nabycie VRE podczas pobytu w IPCZD w wyniku transferu horyzontalnego między pacjentami (np. w przypadku pobrania wymazu z odbytu nie $w$ dniu przyjęcia, ale po 2 lub więcej dniach pobytu na oddziale). W ramach dochodzenia epidemiologicznego w IPCZD wykonano typowanie genetyczne metodą PFGE 43 izolatów VRE wyizolowanych w pierwszym półroczu 2016 i 14 izolatów z roku 2015. Typowanie 24 szczepów VRE pochodzących $\mathrm{z}$ tego samego okresu, wykonane dla dwóch innych szpitali (Szpitala Grochowskiego w Warszawie i Szpitala Wojewódzkiego w Siedlcach) pozwoliło na porównanie genetyczne szczepów występujących w regionie.

\section{MATERIAEY I METODY}

Do typowania genetycznego włączono wszystkie izolaty Enterococcus faecium VRE uzyskane od pacjentów IPCZD w pierwszym pótroczu 2016 roku oraz 14 izolatów z ostatniego kwartału 2015 roku oraz wszystkie izolaty (20 szczepów) nadesłane przez Szpital Wojewódzki w Siedlcach i Szpital Grochowski w Warszawie (4 szczepy), pochodzące $\mathrm{z}$ analogicznego okresu. Izolaty te uzyskano z następujących materiałów: wymaz z odbytu (57, z czego 25 / 44\% pobrano w dniu przyjęcia), krew (2), mocz (6), rana (10), mini BAL (1), wymaz z jamy brzusznej (3), końcówka dojścia centralnego (1) - wymienione materiały kliniczne pobierano podczas hospitalizacji. Ponadto do badania włączono jeden izolat środowiskowy z IPCZD wymaz z czujnika pomiaru temperatury na skórze.

W okresie, z którego pochodzą badane szczepy (1.10.2015 - 31.07.2016) do Kliniki Intensywnej Terapii i Patologii Noworodka (OITN) IPCZD ogółem przyjęto 1665 pacjentów; od 1349 z nich pobrano wymazy obwodowe w dniu przyjęcia. Z 47 szczepów VRE pochodzących z wymazów z odbytu pobranych w IPCZD, 35 wyizolowano w dniu przyjęcia do szpitala, pozostałe 12 izolatów pochodziło z wymazów przesiewowych, pobieranych w ciągu 7- 54 dni hospitalizacji (średnio po 14 dniach; w Klinice Neonatologii badania przesiewowe wykonywane są dodatkowo raz w tygodniu u każdego pacjenta). Wszystkie wyizolowane w IPCZD szczepy VRE (łącznie 57) poddano typowaniu: 47 szczepów z odbytu (każdy od innego dziecka), 5 szczepów z moczu, 4 z rany i 1 z krwi. Wszystkie materiały (oprócz wymazów z odbytu) w szpitalu w Siedlcach (mocz-4, wymaz z rany -4, mini BAL -1, wymaz z jamy brzusznej -3, końcówka dojścia centralnego -1, oraz w Szpitalu Grochowskim (krew, mocz i 2 wymazy $z$ rany) pobrano ze względów klinicznych w trakcie hospitalizacji (w ciągu 5-28 dni od przyjęcia, średnio w ciągu 12 dni). Badane w Siedlcach wymazy z odbytu pobrano już po wyizolowaniu VRE z innych materiałów klinicznych, aby potwierdzić lub wykluczyć kolonizację. Badania śro- 
and the small equipment), among which found the PFGE typed VRE isolate on the temperature sensor, was taken in cohortation room for patients with VRE. The environmental samples was incubate in the tripticsoy broth before the agar plates inoculation in order to increase of bacteria recovering after disinfection.

The study of the VRE colonization at the staff conducted once, testing rectal swabs from all the staff of OITN in time of the highest frequency of VRE isolation; in any case not detected the VRE colonization.

The identification of microorganisms was carried out with a VITEK2 (bioMerieux) apparatus, glycopeptide resistance was confirmed using strips saturated with vancomycin in concentration gradient (bioMerieux), and the results were interpreted according to the European Committee on Antimicrobial Susceptibility Testing (EUCAST) criteria.

Genetic typing: the PFGE genetic typing consists in a comparison of restriction patterns of the genome DNA of a bacterium digested with an enzyme recognizing a relatively small amount of targets. Enzymes appropriately chosen for a bacteria type make it possible to obtain a clear restriction profile that contains a dozen or so DNA fragments - electrophoretic bands - and is the basis for the comparison and the interpretation within the categories identical/ similar/different. Isolation of bacterial chromosomal DNA, digestion and electrophoresis were carried out according to the methodology described in references $(13,14)$.

\section{RESULTS}

Three groups of clonal strains were discovered among the strains from IPCZD:

In case of the most numerous clone I (24 strains) the first isolate was obtained from a female patient of the Neonatal Intensive Care Unit (OITN) in January 2016 (19 strains belonging to the clone were isolated in this unit in total); strains that belonged the clone were also isolated in 4 patients from the Urology Unit (OUR; two children from the OITN spent a short period of time also in the OUR) and in one patient from the pediatric unit. In the case of 12 VRE strains we was documented colonization of patients at admission, other 12 isolates was recovered during hospitalization. Restriction patterns of clone I strains are identical (Fig. 1).

The strains that belonged to clone II (20 isolates) appeared in 2015. 14 isolates were from the OITN (the first patient in December 2015), 3 strains from the OUR (one of the three patients was in the OITN in October 2015, and in March 2016 - in the OUR), 2 strains from the surgical unit, 1 strain from the neurosurgery unit, 1 strain from the pediatric unit (patient was subsequently dowiskowe w IPCZD (wymazy z aparatury medycznej, mebli, drobnego sprzętu), w wyniku których uzyskano włączony do typowania izolat VRE znaleziony na czujniku temperatury, robione były w sali kohortacji dzieci skolonizowanych VRE. Wymazy środowiskowe przed posiewem na podłoże agarowe inkubowano w podłożu płynnym tryptozo-sojowym, aby zwiększyć odzysk drobnoustrojów z powierzchni po dezynfekcji.

Badania nosicielstwa VRE u personelu wykonano jednorazowo, pobierając wymazy z odbytu od wszystkich pracowników OITN IPCZD w okresie najczęstszych izolacji tego drobnoustroju; w żadnym przypadku nie stwierdzając nosicielstwa.

Identyfikację drobnoustrojów wykonano w aparacie VITEK2 (bioMerieux), oporność na glikopeptydy potwierdzono za pomocą pasków wysyconych wankomycyną w gradiencie stężeń (bioMerieux), interpretując wyniki zgodnie z kryteriami The European Committee on Antimicrobial Susceptibility Tessting (EUCAST).

Typowanie genetyczne: Typowanie genetyczne metodą PFGE polega na porównaniu wzorów restrykcyjnych DNA genomowego bakterii trawionego enzymem rozpoznającym stosunkowo niewielką liczbę miejsc działania. Odpowiednio dobrane dla rodzaju bakterii enzymy pozwalają uzyskać czytelny profil restrykcyjny zawierający kilkanaście fragmentów DNA - prążków elektroforetycznych będący podstawą porównania i interpretacji w kategoriach identyczny / podobny / różny (12). Izolację chromosomalnego DNA bakterii, trawienie oraz elektroforezę wykonano zgodnie z metodyką opisaną w literaturze $(13,14)$.

\section{WYNIKI}

Wśród szczepów z IPCZD wykryto 3 grupy szczepów klonalnych:

W przypadku najliczniejszego klonu I (24 szczepy) pierwszy izolat uzyskano od pacjentki OITN w styczniu 2016 roku (ogółem w tym oddziale wyizolowano 19 szczepów należących do tego klonu); szczepy należące do tego klonu wyizolowano także od 4 pacjentów z OUR (dwoje dzieci z OITN przebywało także krótko na OUR) oraz od jednego pacjenta $\mathrm{z}$ oddziału pediatrycznego. W przypadku 12 izolatów VRE udokumentowano kolonizację dzieci w dniu przyjęcia, pozostałe 12 szczepów wyizolowano $\mathrm{w}$ trakcie hospitalizacji. Wzory restrykcyjne szczepów należących do klonu I są identyczne (Ryc. 1).

Szczepy należące do klonu II (20 izolatów) pojawily się w 2015 roku. 14 izolatów pochodziło z OITN (pierwszy pacjent $\mathrm{w}$ grudniu 2015), 3 szczepy z OUR (jeden $\mathrm{z}$ trzech pacjentów w październiku 2015 roku leżał w OITN, a w marcu 2016 roku w OUR), 2 szczepy z oddziału chirurgii, 1 szczep z oddziału neurochirurgii, 1 szczep z oddziału pediatrycznego (pacjent następnie został przeniesiony do OITN). Wzory restrykcyjne szcze- 
transferred to the OITN). Restriction patterns of strains that belongs to clone II are very similar but not identical (fig. 1). Patients who were the link between the two units were identified, just like in case of the clone I strains. VRE strains from the surgical and neurosurgery units were isolated in December 2015. pów należących do klonu II są bardzo podobne ale nie identyczne (Ryc.1). Podobnie jak w przypadku szczepów należących do klonu I, zidentyfikowano pacjentów - ogniwa łączące oba oddziały. Szczepy VRE z chirurgii i neurochirurgii wyizolowano w grudniu 2015 roku. W przypadku 12 izolatów VRE z tego klonu udokumentowano kolonizację dzieci w dniu przyjęcia, pozostałe 8 szczepów wyizolowano w trakcie hospitalizacji.

Clone I: lanes: 1, 34, 6-12, 14-17; clone II: lanes: 5, 13, 18,19

Klon I: ścieżki: 1, 34, 6-12, 14-17; klon II: ścieżki: 5, 13, 18,19

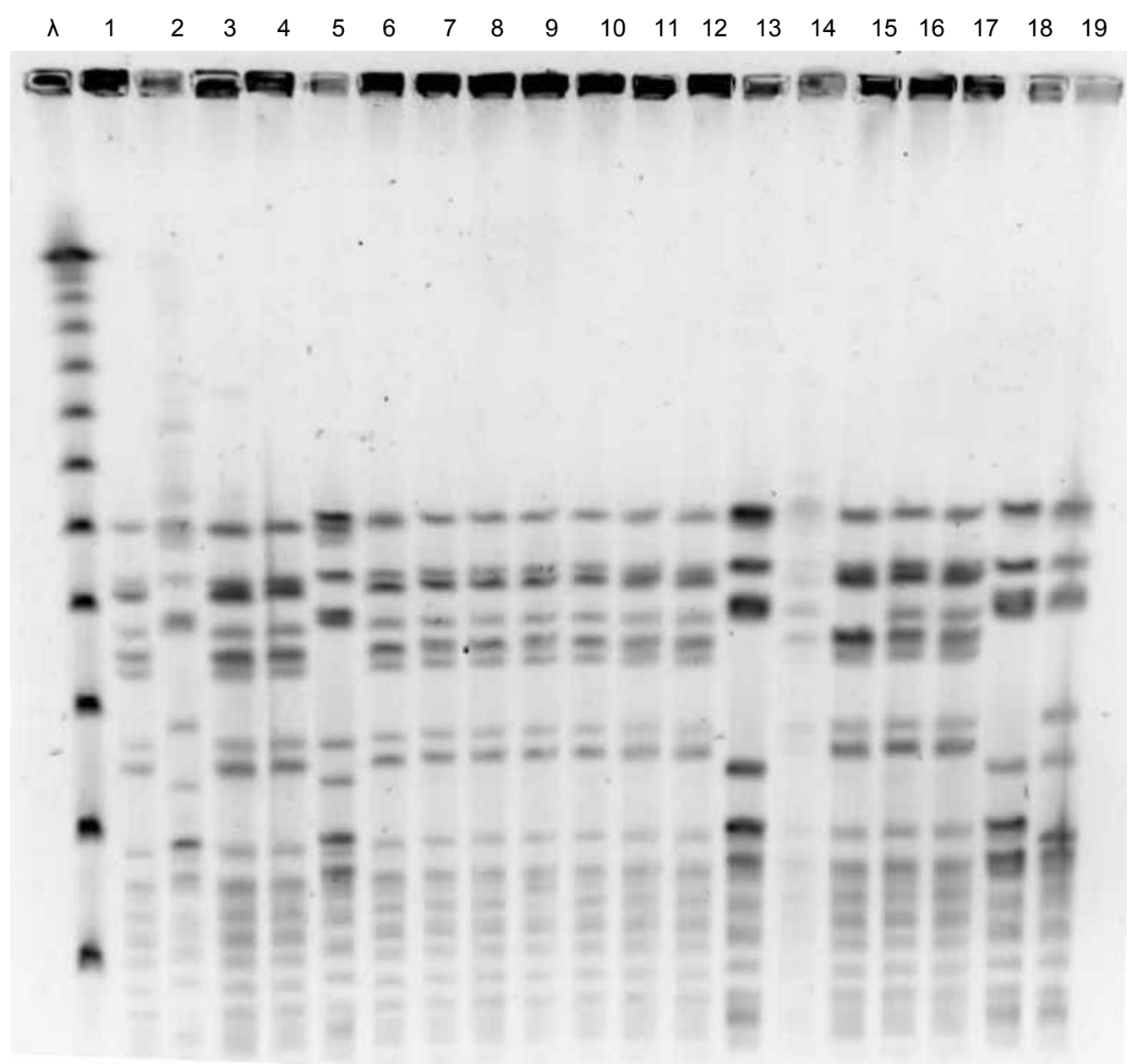

Fig. 1 Example of VRE typing (PFGE; restriction patterns obtained after SmaI digestion); lanes 1-19: VRE strains from OITN CZD isolated 27.01.2015 - 27.04.2015 (period of highest frequency of VRE isolation), $\lambda$ - size marker $\lambda$-ladder (Bio-Rad)

Ryc. 1 Przykładowy rozdział elektroforetyczny (PFGE) DNA VRE trawiony SmaI; ścieżki 1-19: szczepy z OITN CZD izolowane w dniach 27.01.2015 - 27.04.2015 (okres najwyższej częstości izolacji VRE), $\lambda$ - wzorzec wielkości $\lambda$-ladder (Bio-Rad)t

Clone III is 1 strain from an OITN patient from February 2016 (was isolated at admission) and a strain similar to it, isolated in March 2016 from a patient from the surgical unit (was isolated during hospitalization). These children were never in the same place.

Other strains from the children from the surgical unit, recovered during hospitalization, differed from each other and from the OITN strains.
Klon III to jeden szczep od pacjenta OITN z lutego 2016 roku (uzyskany w dniu przyjęcia) oraz podobny do niego szczep od pacjenta $z$ oddziału chirurgii wyizolowany w marcu 2016 roku (uzyskany w trakcie hospitalizacji). Dzieci te w żadnym okresie nie przebywały w tym samym miejscu.

Pozostałe 3 szczepy wyizolowane od dzieci w trakcie hospitalizacji w oddziale chirurgii różniły się między sobą oraz od szczepów z OITN. 


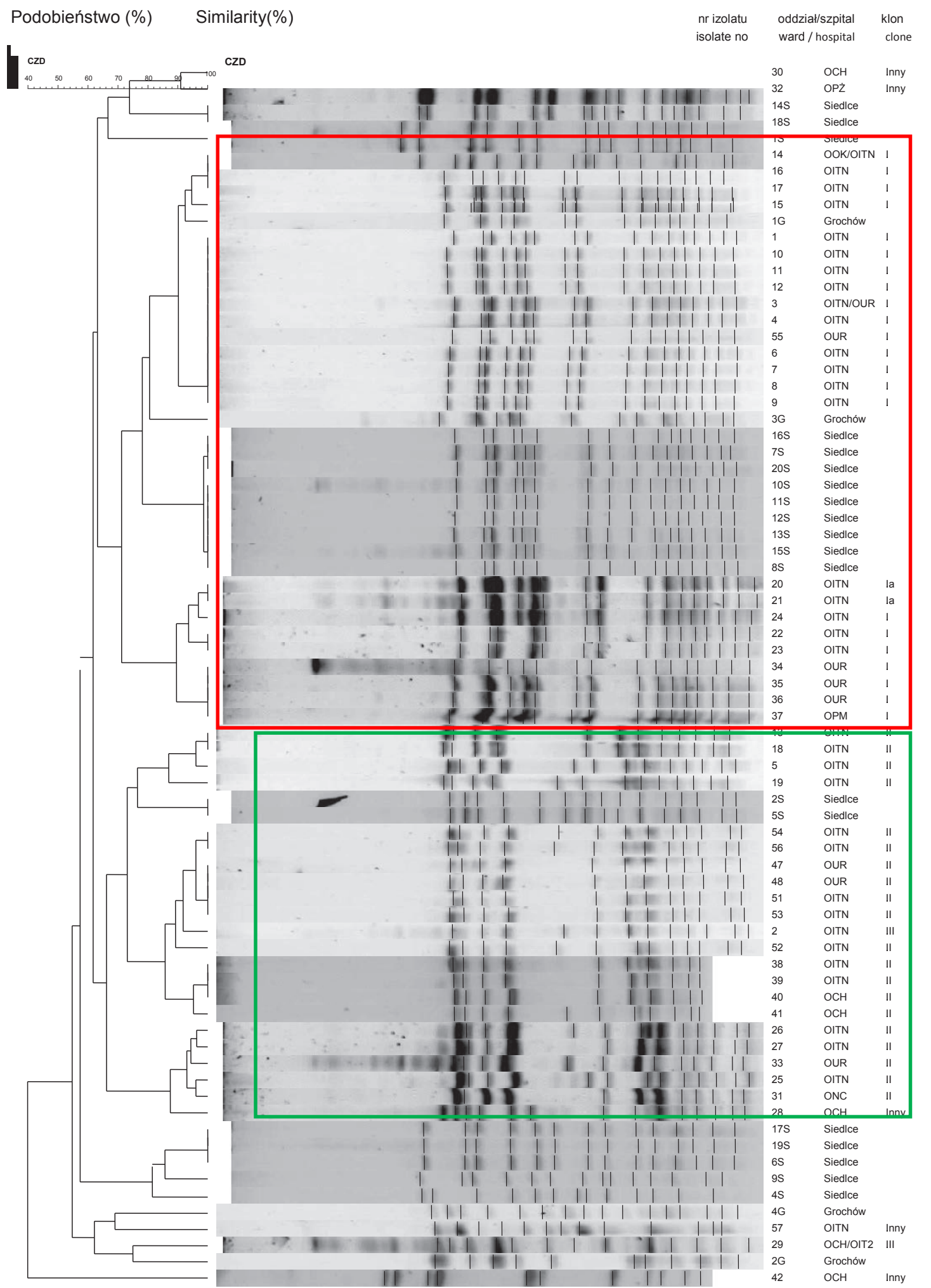

Fig. 2 Restriction analysis of all VRE strains typed - groups of clonal strains are inframed

Ryc. 2 Analiza wzorów restrykcyjnych wszystkich typowanych szczepów VRE - ramką zaznaczono grupy szczepów klonalnych

Abbreviations in right side of the photo indicate wards / hospitals, where VRE were isolated: OCH - General Surgery IPCZD, OPM - Pediatrics, Nutrition and Metabolic Diseases Ward IPCZD, Siedlce - Hospital in Siedlce, OOK - Ophthalmology Ward IPCZD, OITN - Neonatal Intensive Care IPCZD, OUR - Urology IPCZD, Grochów - Grochowski Hospital in Warsaw, ONC - Neurosurgery IPCZD, OIT2 - Intensive Therapy IPCZD Inny - oznacza szczep nie klonalny Inny - means other, non clonal strain

Skróty z prawej strony zdjęcia oznaczają oddziały / szpitale, z których pochodziły izolaty VRE, w kolejności występowania: OCH - Oddział Chirurgii Ogólnej IPCZD, OPM - Oddział Pediatrii, Żywienia i Chorób Metabolicznych IPCZ, Siedlce - Szpital w Siedlcach, OOK - Oddział Okulistyki IPCZD, OITN - Oddział Intensywnej Terapii Noworodka IPCZD, OUR - Oddział Urologii IPCZD, Grochów - szpital Grochowski w Warszawie, ONC - oddział Neurochirurgii IPCZD, OIT2 - Oddział Intensywnej Terapii II - IPCZD 
The environmental strain that belonged to clone I was isolated from a body temperature sensor on skin that was used in an OITN patient in whom VRE colonization was not found. The child was in the unit briefly and the VRE-negative rectal swab was taken on the same day as the sensor swab. VRE strains (not typed) were also found on several other objects of multiple use as well as on the phone in the room were the children colonized by VRE were cohorted.

4 groups of clonal strains were found among the 20 VRE isolates from the hospital in Siedlce; 1 strain did not belong to any of the clones. Most of the clonal strains had identical restriction patterns. Restriction patterns of 8 strains that belonged to one of the clones from Siedlce were very similar to the isolates from IPCZD that belonged to clone I.

Four typed strains from the Grochowski Hospital in Warsaw proved unrelated, but the restriction pattern of one of these strains was very similar to the isolates from IPCZD that belonged to clone I.

VRE strain typing results are depicted in Fig. 2.

\section{DISCUSSION}

We can find confirmation of our results and observations in the publications describing VRE outbreaks. In a university hospital for adults in Wales (15) 134 environmental isolates of vancomycinresistant Enterococci were found within three months (89 E. faecium) and 45 E.faecalis) as well as 24 clinical isolates (20 E. faecium and 4 E. faecalis) isolated from 14 patients. 16 pulse types of the E. faecium and 8 pulse types of the E. faecalis were isolated with the use of the PFGE method. Among the clinical isolates 11 clones were found out, of which strains belonging to 8 of them existed also in the environment. The strains that belonged to heterogeneous environmental population were isolated from blood, urine, bile, dialysis fluid from patients. The dominating pulse type - clone E. faecium of 11 strains did not exist in the environment which indicates that VRE strains may be transferred among patients without the environment being involved. In patient rooms VRE were isolated from bed frames, chairs, counters, television sets, door handles and window handles, room dividers, shelves. The tests were carried out in 2000; it was the first genetic typing of VRE in Wales. The spread of VRE strains in the environment could be caused by the low awareness of the threat posed by infections caused by these bacteria and suggested insufficient compliance with hygiene standards. VRE was isolated in the intensive care, surgical, hematological and nephrology units. It is likely that other bacterial pathogens were also commonly present in the environment. During our epidemiological investigation, conducted in the neonatal unit 15 years later, finding the environmental strains was very difficult;
Szczep środowiskowy, należący do klonu I, wyizolowano z czujnika pomiaru temperatury na skórze używanego u pacjenta OITN, u którego nie wykryto kolonizacji VRE. Dziecko przebywało krótko w oddziale, a ujemny pod względem VRE wymaz z odbytu miało pobrany tego samego dnia, w którym pobrano wymaz z czujnika. Szczepy VRE (nie typowane) wykryto także na kilku innych przedmiotach wielokrotnego użyt$\mathrm{ku}$, a także na telefonie w sali, w której zorganizowano kohortację dzieci skolonizowanych VRE.

Wśród 20 izolatów VRE ze szpitala w Siedlcach wykryto 4 grupy szczepów klonalnych; 1 szczep nie należał do żadnego z klonów. Szczepy klonalne w większości miały identyczne wzory restrykcyjne. 8 szczepów należących do jednego z klonów z Siedlec miało wzory restrykcyjne bardzo podobne do izolatów z IPCZD należących do klonu I.

Cztery typowane szczepy ze szpitala Grochowskiego w Warszawie okazały się niespokrewnione ze sobą, ale jeden z tych szczepów miał wzór restrykcyjny bardzo podobny do izolatów z IPCZD należących do klonu I.

Wyniki typowania wszystkich szczepów VRE przedstawia Ryc. 2.

\section{DYSKUSJA}

Wiele wcześniejszych publikacji opisujących epidemie VRE potwierdza nasze wyniki i obserwacje. W szpitalu uniwersyteckim dla dorosłych w Walii (15) w czasie 3 miesięcy uzyskano 134 izolaty środowiskowe enterokoków opornych na wankomycynę ( 89 E. faecium i 45 E. faecalis) oraz 24 izolaty kliniczne ( 20 E. faecium i 4 E. faecalis) wyizolowane od 14 pacjentów. Metodą PFGE zidentyfikowano 16 pulsotypów E faecium i 8 pulsotypów $E$. faecalis. Wśród izolatów klinicznych wykryto 11 klonów, z czego szczepy należące do ośmiu z nich występowały także w środowisku. Szczepy należące do heterogennej populacji środowiskowej izolowano z krwi, moczu, żółci, płynu dializacyjnego od pacjentów. Dominujący pulsotyp - klon E. faecium, liczący 11 szczepów, nie występował w środowisku, co wskazuje na przenoszenie szczepów VRE miedzy pacjentami także bez udziału środowiska. W salach pacjentów VRE izolowano z ram łóżek, krzeseł, blatów, telewizora, klamek drzwi i okien, parawanów, półek. Badania wykonano w 2000 roku; było to pierwsze typowanie genetyczne VRE w Walii. Rozpowszechnienie szczepów VRE w środowisku mogło być spowodowane niską świadomością zagrożenia, jakie niosą zakażenia tymi bakteriami i świadczyło o niedostatecznym przestrzeganiu zasad higieny. VRE izolowano w oddziale intensywnej terapii, chirurgii, hematologii i nefrologii. Prawdopodobnie równie licznie występowały w środowisku inne patogeny bakteryjne. W naszym dochodzeniu epidemiologicznym, prowadzonym w oddziale noworodkowym 15 lat później, znalezienie szcze- 
they were found on a telephone receiver and on the multiuse temperature sensors that underwent disinfection.

Different observation results were obtained as a result of an epidemiological investigation in an academic hospital in Turkey. (16). After isolating $E$. faecium VRE from the blood of five patients from the hematological unit, an epidemiological investigation was conducted. The investigation consisted in analysis of rectal swabs from the patients and the staff as well as from the environment. The tests were carried out over a period of 6 months since May 2006 when the first VRE strain was isolated from a patient of this unit. The rectal swab screening proved VRE colonization in 7 patients out of which 5 developed VRE bacteraemia. The strains isolated from individual patients were non-clonal which suggests independent introductions into the hospital. The VRE was not found to be present in the samples taken from the environment and the staff. The authors did not describe the methodology of the environmental swab screening in detail but our experience shows that at a low level of VRE contamination, especially in rooms that are often cleaned and disinfected, an incubation of swabs in proliferating liquid medium before plating on agar medium is necessary. However, the lack of VRE presence in the staff is compliant with our results of the epidemic investigation and confirms the thesis that staff colonization does not play a role in VRE transmission among the patients. Independent introductions of VRE strains that appear when new patients are admitted, occur simultaneously with VRE horizontal transmission in a unit, which has been proven in our hospital. Similar observations in a pediatric hospital were described by Barnaud and Bingen in 2000 (17). They identified 11 PFGE sub-types among 36 isolates. Initially the strains that were isolated belonged to one clone which indicates horizontal transmission after the introduction of the first strain - which is what the authors suggest; or it could be the result of independent introduction of clonal strains that occur also in non-hospital environment - which is also shown by our experience. The fact that some strains studied by us were similar but not identical indicates occurrence of clonal strains and ongoing diversification during passages in the environment outside of our hospital, and independent introduction. Restriction patterns that belong to clone I are very homogeneous, which suggest that the strains are closely related; such result proves also currently ongoing horizontal spreading of clonal strains, as well in IPCZD as in environment. In case of half of strains that belongs to clone I we documented its introduction to the our hospital. Others 12 isolates was recovered during hospitalization; but five from colonized children don't have rectal swab at admission tested and thereby the history of their VRE is unknown. A long period over which clonal strains from clone II were isolated is reflected by a certain diversification of pów środowiskowych było bardzo trudne; wykryto je na słuchawce telefonu oraz na poddawanych dezynfekcji czujnikach temperatury wielokrotnego użytku.

Odmienne obserwacje uzyskano w wyniku dochodzenia epidemiologicznego w szpitalu akademickim w Turcji. (16). Po wyizolowaniu E. faecium VRE z krwi pięciu pacjentów oddziału hematologicznego przeprowadzono dochodzenie epidemiologiczne polegające na badaniu wymazów z odbytu pacjentów i personelu oraz ze środowiska. Badania wykonano na przestrzeni pół roku, odkąd w maju 2006 roku wyizolowano od pacjenta tego oddziału pierwszy szczep VRE. Skrining wymazów z odbytu wykazał kolonizację VRE u 7 pacjentów, z czego u pięciu pacjentów rozwinęła się bakteriemia VRE. Szczepy izolowane od poszczególnych pacjentów były nieklonalne, co świadczy o niezależnych introdukcjach do szpitala. Nie stwierdzono obecności VRE w próbkach pobranych ze środowiska i od personelu. Autorzy nie opisali dokładnie metodyki posiewu wymazów środowiskowych, lecz nasze doświadczenie pokazało, że przy niskim poziomie skażenia VRE, zwłaszcza w pomieszczeniach często sprzątanych i dezynfekowanych, do wyhodowania VRE niezbędna jest inkubacja wymazów w namnażającym podłożu płynnym przed posiewem na podłoża agarowe. Natomiast brak VRE u personelu jest zgodny z naszymi wynikami dochodzenia epidemiologicznego i potwierdza tezę, że kolonizacja personelu nie odgrywa roli w transmisji VRE wśród pacjentów. Niezależne introdukcje szczepów VRE pojawiających się wraz z nowymi pacjentami, przebiegają równolegle $\mathrm{z}$ transmisją horyzontalną VRE w oddziale, co potwierdziliśmy w naszym szpitalu. Podobne obserwacje w szpitalu pediatrycznym opisali Barnaud i Bingen w 2000 roku (17). Wśród 36 izolatów zidentyfikowali 11 podtypów PFGE. W początkowym okresie izolowano szczepy należące do jednego klonu, co wskazuje na transmisję horyzontalną po introdukcji pierwszego szczepu - co sugerują autorzy; lub może być wynikiem niezależnych introdukcji szczepów klonalnych występujących w środowisku pozaszpitalnym - na co wskazuje także nasze doświadczenie. Fakt, że niektóre z badanych przez nas szczepów były podobne, a nie identyczne, wskazuje na występowanie szczepów klonalnych i postępujące różnicowanie w trakcie pasażowania $\mathrm{w}$ środowisku poza naszym szpitalem i niezależną introdukcję. Wzory restrykcyjne szczepów należących do klonu I są identyczne, co sugeruje bardzo bliskie pokrewieństwo szczepów; taki wynik świadczy o aktualnie trwającym horyzontalnym rozprzestrzenianiu się szczepów klonalnych, zarówno w IPCZD, jak i w środowisku pozaszpitalnym. W przypadku połowy z 24 szczepów klonu I udokumentowano introdukcję do szpitala. Pozostałe 12 szczepów wyhodowano od dzieci $\mathrm{w}$ trakcie hospitalizacji, ale pięcioro $\mathrm{z}$ nich nie miało pobranego wymazu $\mathrm{z}$ odbytu $\mathrm{w}$ dniu przyjęcia i historia nabycia VRE jest u nich nieznana. Długi okres, na przestrzeni którego izolowano szczepy należące do klonu II, 
their restriction patterns - they are closely related but not identical. Most of the rectal swabs were taken on the day of admission (12/20), which indicates independent introduction of VRE into our hospital and may suggest that clone II strains occur also outside of it. In case 2 isolates from clone II we can't confirm their origin due the lack of rectal swab at admission. The occurrence of clonal isolates in two units is related to the transfers of children between the units; then the horizontal spread occurs (transfer by hands or minor equipment) within the unit.

An earlier test from 2008 (18), carried out in pediatric unit in reference hospital in Turkey, showed the presence of two dominating pulse types of $E$. faecium VRE (strains 8 and 4) and a few non-clonal strains, just like in IPCZD. In total, 36 isolates were obtained from 36 patients, out of which six had VRE present in the digestive tract, and four developed infections of the urinary system or bacteraemias. Among the 56 patients of IPCZD in whom VRE was isolated, bacteraemia ocurred only in one. 5 isolates from urine likely resulted from urine sample contamination with VRE from the rectum, and 4 isolated from wounds were taken from patients with no symptoms of infection. All Turkish VRE strains belonged to an epidemic clone being a part of a clonal complex - 17 (CC-17 complex). This complex dominates also in Poland (19) and the strains that it encompasses have virulence factors that enable their survival in the environment and long-term colonization. These strains produce the Esp superficial protein, hyaluronidase and protein binding collagen; it is probably these factors that enable them to cause more severe infections $(4,19,20)$.

The occurrence of clonal E. faecium strains on the entire territory of Italy was described by Stampone (21) after studying 31 VRE strains isolated from the blood of patients in various laboratories between the years 2001 and 2003. 28 out of 31 belonged to the dominating clone. The allelic profile in MLST was identified as ST78 belonging to the $\mathrm{C} 1$ clonal line. These strains frequently cause infections in people and are responsible for hospital outbreaks.

The data above indicate that VRE clonal strains may occur on relatively large areas which is also confirmed by our study.

\section{CONCLUSIONS}

1. The occurrence of VRE in IPCZD is the result of horizontal spreading of clonal strains and, at the same time, of independent introductions of strains circulating in the non-hospital environment and of strains from other hospitals.

2. VRE strains that belong to the same clone appear in a few hospitals. znajduje odbicie w pewnym zróżnicowaniu ich wzorów restrykcyjnych - są one blisko spokrewnione, ale nie identyczne. Większość wymazów z odbytu, z których wyhodowano szczepy klonu II było pobranych w dniu przyjęcia (12/20), co wskazuje na niezależne introdukcje VRE do naszego szpitala i świadczy o występowaniu tego klonu także poza IPCZD. Wśród pozostałych ośmiu szczepów klonu II w przypadku dwóch szczepów z powodu braku badania „na wejściu” nie można potwierdzić ich pochodzenia. Występowanie izolatów klonalnych $\mathrm{w}$ dwóch oddziałach jest związane z przenoszeniem dzieci pomiędzy tymi oddziałami; następnie zachodzi rozprzestrzenienie horyzontalne (przeniesienie poprzez ręce lub drobny sprzęt) w obrębie oddziału.

Wcześniejsze badanie z 2008 r. (18) przeprowadzone na oddziale dziecięcym w szpitalu referencyjnym w Turcji wykazało obecność 2 dominujących pulsotypów $E . f a-$ ecium VRE (8 i 4 szczepy) oraz kilku szczepów nieklonalnych, podobnie jak w IPCZD. Ogółem uzyskano 36 izolatów VRE od 10 pacjentów, z których sześciu było tylko nosicielami VRE w przewodzie pokarmowym, natomiast u czterech wystąpiło zakażenie układu moczowego lub bakteriemia. Wśród 56 pacjentów IPCZD, od których wyizolowano VRE, tylko u jednego wystąiła bakteriemia; 5 izolatów z moczu było prawdopodobnie zanieczyszczeniem próbki moczu przez VRE z odbytu, a 4 izolaty z rany pobrano od pacjentów bez objawów zakażenia. Wszystkie tureckie szczepy VRE należały do epidemicznego klonu będącego częścią kompleksu klonalnego -17 (CC-17). Kompleks ten także dominuje w Polsce (19), a należące do niego szczepy są obdarzone czynnikami wirulencji umożliwiającymi przetrwanie w środowisku i długotrwałą kolonizację. Szczepy te wytwarzają białko powierzchniowe Esp, hialuronidazę i białko wiążące kolagen; prawdopodobnie dzięki tym czynnikom wywołują zakażenia o cięższym przebiegu $(4,19,20)$.

Występowanie szczepów klonalnych E.faecium na terenie całego kraju opisała we Włoszech Stampone (21), badając 31 szczepów VRE wyizolowanych $\mathrm{z}$ krwi pacjentów $\mathrm{w}$ różnych laboratoriach $\mathrm{w}$ latach 2001-2003. Dwadzieścia osiem z 31 szczepów należało do dominującego klonu. Profil alleliczny w MLST zidentyfikowano jako ST78, należący do linii klonalnej C1. Szczepy te z dużą częstością wywołują zakażenia u ludzi i odpowiadają za epidemie szpitalne.

Powyższe dane wskazują, że szczepy klonalne VRE mogą występować na stosunkowo dużych obszarach, co potwierdza również nasze badanie.

\section{WNIOSKI}

1. Występowanie VRE w IPCZD jest wynikiem rozprzestrzenienia horyzontalnego szczepów klonalnych, oraz, jednocześnie, niezależnych introdukcji szczepów krążących w środowisku pozaszpitalnym i szczepów z innych szpitali. 
3. Identical restriction patterns within a clone indicate that strains have been introduced into the hospital recently and that they have colonized many patients and that currently an ongoing horizontal transmission is taking place.

\section{REFERENCES}

1. Cetinkaya Y, Falk P, Mayhal CG. Vancomycin-resistant enterococci. Clin Microbiol Rev 2000;13: 686-707

2. Boyd DA, Willey BM, Fawcett D , et al.. Molecular characterization of Enterococcus faecalis N06-0364 with low-level vancomycin resistance harboring a novel d-Ala-d-Ser gene cluster, vanL. Antimicrob Agents Chemother 2008;52:2667-2672

3. O'Driscoll T, Crank CW. Vancomycin-resistant enterococcal infections: epidemiology, clinical manifestations, and optimal management. Infect Drug Resist 2015; 8: 217-230.

4. Wardal E, Hryniewicz W. Enterokoki oporne na wankomycynę - groźny patogen zakażeń szpitalnych. Nowa Klin Med Zakażeń 2009; 16: 711-716

5. Bronk M, Samet A, Hellmann A,et al. Izolacja wankomycynoopornego Enterococcus faecium (VREM) od pacjentów Kliniki Hematologii. Klinika Chorób Zakaźnych i Zakażenia Szpitalne 1997;2, 71-74

6. European Centre for Disease Prevention and Control. Antimicrobial resistance surveillance in Europe 2016. Annual Report of the European Antimicrobial Resistance Surveillance Network (EARS-Net). Stockholm: ECDC;2018.

7. Krawczyk B, Samet A, Bronk M, et al.. Emerging linezolid resistant, vancomycin resistant Enterococcus faecium from a patient of a haematological unit in Poland. Pol J Microbiol 2004; 53: 193-196.

8. Wardal E, Markowska K, Żabicka D, et al. Molecular Analysis of VanA outbreak of Enterococcus faecium in Two Warsaw Hospitals: The Importance of Mobile Genetic Elements. BioMed Res Int 2014; ID 575367.

9. Szczypta A, Talaga K, Bulanda M. Enterokoki oporne na wankomycynę jako czynniki etiologiczne zakażeń związanych z opieką zdrowotną - chorobotwórczość i metody kontroli. Hygeia Public Health 2016; 51(2):134-140

10. Patel R, Gallagher JC. Vancomycin-resistant enterococcal bacteremia pharmacotherapy. Ann Pharmacother 2015;49(1): 69-85.

11. Suzuki M, Koyano S, Okugawa S,et al. Diversity of vancomycin-resistant enterococci in a low endemicity area. J Glob Antimicrob Resist 2014;2: 115-118.

12. Tenover FC, Arbeit, RD, Goering RV, et al. Interpreting chromosomal DNA restriction patterns produced by pulsed- field gel electrophoresis: Criteria for bacterial strain typing. Journal of Clinical Microbiology 1995; 33(9), 2233-2239.

13. Saeedi B, Hallgren A, Jonasson J, et al. Modified pulsedfield gel electrophoresis protocol for typing enterococci. APMIS 2002;110: 869-74.
2. Szczepy VRE należące do tego samego klonu występują w kilku szpitalach.

3. Identyczne wzory restrykcyjne $\mathrm{w}$ obrębie klonu świadczą o niedawnym wprowadzeniu szczepów do szpitala, które skolonizowały wielu pacjentów, $\mathrm{i}$ trwającej aktualnie transmisji horyzontalnej.

14. Turabelidze D, Kotetishvill M, Kreger A, et al. Improved pulsed-field gel electrophoresis for typing vancomycinresistant entrococci. J Clin Microbiol 2000: 38(11): 4242-45.

15. Kuriyama T, Williams DW, Patel M, et al. Molecular characterization of clinical and environmental isolates of vancomycin-resistant Enterococcus faecium and Enterococcus faecalis from a teaching hospital in Wales. J Med Microbiol 2003;52, 821-827.

16. Kirdar S, Sener AG, Arslan U, Yurtsever SG. J. Molecular epidemiology of vancomycin-resistant Enterococcus faecium strains isolated from haematological malignancy patients in a research hospital in Turkey. Med. Microbiol 2010; 59: 660-664

17. Barnaud G, Bingen E. Genotyping characterisation of endemic VanA Enterococcus faecium strains isolated in a paediatric hospital. J Med Microbiol 2000; 49: 793799

18. Ergani-Ozcan A, Naas T, Ozhak Baysan B, et al. Nosocomial outbreak of vancomycin-resistant Enterococcus faecium in a paediatric unit at a Turkish university hospital. J Antimicrob Chemother 2008; 61: 1033-1039

19. Top J, Willems R, Blok H, et al. Ecological replacement of Enterococcus faecalis by multiresistant clonal complex 17 Enterococcus faecium. Clin Microbiol Infect 2007, 13(3): 316-319.

20. Kowalska-Krochmal B, Dworniczek E, Dolna I, et al. Resistance patterns and occurrence of virulence determinants among GRE strains in southwestern Poland. Adv Med Sci 2011, 56: 304-310

21. Stampone L, Del Grosso M, Boccia D and Pantosti A. Clonal spread of a vancomycin-resistant Enterococcus faecium strain among bloodstream-infecting isolates in Italy. J Clin Microbiol 2005;43(4):1575-80.

Received: 4.02.2019

Accepted for publication: 22.03.2019

Otrzymano: 4.02.2019 r.

Zaakceptowano do publikacji: 22.03.2019 r.

\section{Address for correspondence: \\ Adres do korespondencji:}

Wanda Kamińska,

Instytut "Pomnik-Centrum Zdrowia Dziecka",

04-730 Warszawa, Aleja Dzieci Polskich 20.

Zakład Mikrobiologii i Immunologii Klinicznej 